\title{
THE EFFECT OF EXCHANGE RATE FLUCTUATIONS ON TRADE BALANCE OF PAKISTAN
}

\author{
ARSHAD ULLAH JADOON, YANGDA GUANG
}

\begin{abstract}
:
This main goal of this study is to check the exchange rate fluctuations and its impact on trade balance in Pakistan. The annual time series data from 1971 to 2016 is used to check the short run and long run relationship between Exchange rate fluctuations trade balance of Pakistan. We employed the autoregressive distributed lag approach and results reveal that Exchange rate has positive and significant relationship with balance of trade in long run and short run. Devaluation of Pakistani rupees against USD, would increase the exports and ultimately trade balance will enhance. The inflation and money supply has negative and significant relationship with balance of trade in long run in Pakistan. The excess of money supply will increase inflation which reduces the exports and consequently, balance of trade would decrease. This study has a policy implications for government as well as local and foreign investors. The government should also play an important role to make such strategies which can increase the balance of trade in Pakistan and can boost the economic growth of Pakistan indirectly.
\end{abstract}

\section{Keywords:}

Exchange rate, Balance of Trade, Inflation, Money Supply, exports.

JEL Classification: P33, P34, F10

\section{Authors:}

ARSHAD ULLAH JADOON, Northeast Normal University Changchun china, China, Email: arshadjadoon22@gmail.com YANGDA GUANG, Northeast Normal University Changchun china, China, Email: arshadjadoon22@gmail.com

\section{Citation:}

ARSHAD ULLAH JADOON, YANGDA GUANG (2019). THE EFFECT OF EXCHANGE RATE FLUCTUATIONS ON TRADE BALANCE OF PAKISTAN. International Journal of Economic Sciences, Vol. VIII(1), pp. 68-80., 10.20472/ES.2019.8.1.005 


\section{Introduction}

The exchange rate Fluctuation is not a new phenomenon, and it means that the change in exchange rate more than expectation of any individual. Some researchers stated that Fluctuations is the outcome of the speculators in exchange rate while other researchers proved that Fluctuation is due to monetary policy of any country. Overshooting model was first developed by Dornbusch, a German scientist by keeping in mind sticky price system. The fluctuation of exchange rate has ripple effect on other macroeconomic indicators like some are trade balance, money supply, and inflation, etc. These truth plays a significant role to the economic growth of every economy which opens its doors to international trade in goods and services. Lot of previous researchers like (Alexander, 1952; Harberger, 1950; Meade, 1951; Mundell, 1968) and most recent literature (Bahmani- Oskooee, 1985; Bahmani-Oskooee \& Cheema, 2009; Kale, 2001) show that devaluation of the currency maintains fixed foreign exchange rate which cure to chronic trade imbalances.

Foreign trade can exert a profound influence on the macroeconomic conditions of a country. In the past, because of the closed structure of most of the economies, the governments' activities were limited and the concept of foreign trade was not prevalent. However, with the passage of time and with the interdependence of the economies, the importance of foreign trade has been increased enormously. Goods and services sell to other countries are called exports while goods and services bring from other countries are called imports. The difference between exports and imports is called net export or the balance of trade. If the value of a country's exports exceeds than that of imports, a country will be having a trade surplus, while the opposite case is called trade deficit. Countries that enjoy a trade surplus have more money flowing in than out, more control over its currency value, higher employment rate and high living standards. Whereas deficit in the trade balance put negative effects on the economy.

Trade which recently considering a key injector of economic growth, has gained unexpected importance in the current age of market competition. World became a global village where technology shifted from developed to developing countries. The development and creation of high technology increased dependency of economies on each other since two decades. Demand for product is growing with the rapid increase in population and enhance standard of living.

In this paper, I have tried to link the importance of trade with the economic growth of Pakistan economy in light of various economist views that how trade affect standard of living. A solid comprehensive past studies state that trade affects standard of living in various ways and manners. Trade which creates new opportunities and environment for new investment in the country, can changed the standard life of people by shifting capital to host country and hence the production increasing many times, similarly the export capacity enhancing in the fastest manner. National income increasing, employment opportunities creating. The wage rates go up and finally living of standard become moderate. Elhanan Help man (1990) states that countries which have adopted an outward oriented development strategy have grown faster and achieved a higher level of economic well Bing than those which adopted a conservative strategy of trade. Technology which provide support for economic stability in the long run are the main source of accelerating economic growth of a country. New technology is important factor which transfer to host country and bring drastic changes in economic development. It supports will Bing of the community from the production side. Increase in production not only 
related to technological progress but it also closely connected with stock of knowledge capital and many others factors. Heal (1984) find out that knowhow and technological progress affect the economic growth of a country in long term. Development is not a short- term process it may occur in long run. Full filing, sitting up and understanding of new technologies take many years. Especially for developing countries to understand the new technologies are very difficult.

Echevarria (2008) indicates that global economic changing driven by involving in international trade. The countries which involve in international trade, their general public are more prosperous than those which involve in domestic product only. The role of international trade plays in enhancing economic growth and fulfill the demand for product at domestic level as well as on international level. It increases opportunities of investment in the country to promote standard of life in the country. This issue of discussion adopted serious consideration since 1990 after technological spillover. After technological revolution, international trade came the main discussion of developing economies. Why the developing countries in particular take it so serious to promote the trade position in the country, there are many reasons which compel developing countries to involve in international trade.

The reason of promoting trade and involving in international trade are the globalization and liberalization. Without involving in international trade no country can live alone. In light of absolute advantage theory, no every country specialized in each product. Every economy has need of export and import. To apply this theory every country trying to maximize their product capacity position, therefore they involving in international trade and focusing on absolute advantage theory to creates the specializes product in which their cost and time consuming limited and to import those goods which they can import through minimum cost. Khan (1999) describe that After 1990 people republic of china and other East Asian countries like Singapore and South Korea in particular and some Asian countries in general has gained a huge level of foreign direct investment, therefore their imports Economies shifted to export economies. Involving in international trade and improving standard of life are the main example of these economies that how trade can be enhancing life expectancy of people.

The deficit in the trade balance may be eliminated by various measures, such as imports quotas, supply side policies, deflationary fiscal policy and exchange rate. However amongst all these factors the exchange rate is considered to be an important determinant of trade balance. Earlier research on exchange rate such as Kreinin (1967) and Khan (1974) concentrated on examining whether Marshall-Lerner condition was held or not. Marshall Learner condition postulates that in the long run the balance of trade may be improved if the price elasticity of the demand for imports and the demand for exports exceeds 1 in absolute value. (Marshall, 1923; Lerner, 1944).In spite of the satisfaction of the Marshall-Lerner condition, it was observed that the trade balance has continued to deteriorate. (Bahmani-Oskooee, 1985). This shifted the focus of the researchers from Marshall-Lerner condition to $\mathrm{J}$ curve phenomenon. It was Magee (1973) who introduced the concept of $\mathrm{J}$ curve for the first time. Because of its lag structure, devaluation is said to worsen the trade balance first and then improve it, resembling the letter $\mathrm{J}$. A change in the value of a currency has two effects on trade balance, the price and volume effect. The price effect implies that the depreciation increase import unit value in the short run while the volume of traded goods might not change drastically and hence the trade balance worsens. However later on the devaluation of currency increases the competitiveness in domestic price which leads to more exports than imports, thereby improving the trade balance. Economists have called this tendency of a nation's trade balance to first deteriorate before improving as a result of devaluation or depreciation in the nation's 
currency the J curve effect (Junz and Rhomberg, 1973; Meade, 1988; Bahmani-Oskooee, 1991; Khan and Hassan, 1994).

\subsection{Objectives of the study}

- To examine the impact of exchange rate fluctuations on trade balance of Pakistan.

- To examine the short and long run relationships between exchange rate, Money supply, inflation and trade balance of Pakistan.

\section{Literature Review}

A large number of studies have been undertaken to examine the importance and advantages of international trade. To link international trade in term of importance various Economist, Financial advisors, financial institutions, financial consultancy firms, non-government organizations and political economist have different ideas about trade impact on Economic growth. The majority of the researcher fined that trade and economic growth are deeply connected with each other and trade has effectively accelerated economic growth of a country. These experts says that Economic growth is a comprehensive terminology which associated directly proportionally with international trade. These experts targeted trade impact over economic growth in different views.

Dodzin et al., (2004) indicate that international trade has a great impact on economic growth of a country, Trade shifting the economy from small scale to large scale production and from agricultural sector to industrial sectors which demand for raw material increased and hence the economy growing efficiently from every side, production increasing because of export, industrial sector of the economy boosting rapidly which is considering a sign of increasing international demand for product trade. The allocation of production across sectors in developing countries especially taking place to catch up the position of developing countries. Increase in openness to trade leads to an increase in the industrial value-added share of production, at the expense of the agricultural share. Therefore, trade leads the developing countries to industrialization. High technology transfer to host country, foreign capital starting inward to the host country and the economy grows on fastest way.

Schneider (2002) describes that role of high-technology trade, IPRs and FDI determining a country's rate of innovation and economic growth. They conducted using a unique panel data set of 47 developed and developing countries from 1970 to 1990 and resulted that hightechnology imports are relevant in exploring domestic innovation both inside developing and developed countries. Foreign technology has a stronger impact on per capita GDP growth than domestic technology IPRs affect the innovation rate, but this impact is more significant for developed countries. International trade promoting new technology in the country which directly affecting production and hence trade increased which accelerate national income, resulted Economic growth. R\&D sector growing in a substantial way to help innovation. R\&D sector of the economy closely connected with high technology and education, the main difference between developing and developed countries are the R\&D. In less developed countries R\&D sectors many time low than developed countries, this sector of the economy positively affects production sector of the economy which directly affect economic growth by increasing national income.

Halite (2002) says that trade liberalization has no significant impact on economic growth of a 
country, especially in developing countries of the world where own demand for production are so high which not allowing the economy to export and if they do the same then they will be affected inversely. They presented numerical views as an evidence and show negative impact. Trade barrier is used positive tool which better for developing countries.

Sharif (1981) describes positive relation of trade with economic growth and income inequality. They link economic growth with inequality by using a tool of employment. whenever there is an employment in the country the inequality of income distribution will be reduce and in a result economic growth will be take place. Employment opportunities can increased trade indirectly and reduce inequality of income distribution in a normal economy. Employment Concern of the effectiveness of trade policies and their assessment in achieving economic growth and income equality.

Qureshi (2013) described that spillover effects of regional conflicts, defined as internal or external armed conflicts in contiguous states, on international trade. The impact increases with conflict duration, and is persistent-on average, it takes bilateral trade 3-5 years to recover after the end of a regional conflict. The regional conflicts in term of war, political crisis, internal state trade policies, and many other challenges affect international trade which adversely affect the economic growth of a country. This is an indirect approach towards the economic growth and trade. If these challenges exist in the economy then trade will be reducing and consequences will be further decline the confidence of producers to produce new goods in the market.

Looi Kee. et al., (1998) say that increase in export price, capital stock, and stable inflation are those factors which responsible for the decline of Singapore's unemployment rate over the period 1966-2000. These factors reduce structural unemployment in Singapore during four decades. Also, these factors increased Singapore production capacity into certain level and a result country economy expended many times than before.

Heal (1984) indicates that in a perfectly competitive market, an increase in the exports of a labor-intensive good by a labor-abundant developing country may make the exporter worse, an expansion of labor-intensive exports thus leads to a net transfer of welfare from the exporting to the importing country. Transferring the new ideas and knowhow by supporting labor efficiency are the main role in economic growth of import base economy and thus reached to the top position by adopting new ways of developed economies techniques. This is the basic approach of economic growth to follow the developed economies method of succession.

In the short run the trade balance first deteriorates before it later improves that is exhibiting the $J$ curve pattern. The results obtained are helpful for the policy makers both in Serbia and in a number of other emerging countries as they face current account deficit.

\section{Data and Methodology}

\subsection{Data source and variables selection}

For measuring the effect of exchange rate fluctuations on trade balance of Pakistan we have taken trade balance as dependent variables and foreign exchange rate, inflation and money supply as our independent variables in this study. The annually time series data from 1971 to 2016 were taken from site of world development indicators. 


\begin{tabular}{|l|l|l|}
\hline Variables & Definition & Source \\
\hline BOT & Balance of Trade: Ratio of Exports to Imports & World Development Indicators \\
\hline EXR & $\begin{array}{l}\text { Exchange Rate: Domestic currency (Rupee) } \\
\text { divided by foreign currency (USD) }\end{array}$ & World Development Indicators \\
\hline INF & Inflation: Consumer price Index annually & World Development Indicators \\
\hline MS & $\begin{array}{l}\text { Broad money supply: the sum of currency } \\
\text { Outside banks; demand deposits other than } \\
\text { those of the central government. (\% of GDP) }\end{array}$ & World Development Indicators \\
\hline
\end{tabular}

\subsection{Research Methodology}

\subsubsection{Unit Root Test}

We used unit root test to identify the stationary of the series. One of the advantage of autoregressive distributed lag (ARDL), it can be apply on any combination either 1(0) or 1(1). Further, if we do not check unit root of our variables, then the outcomes can be spurious. We used two methods for Unit Root, Augmented Dickey-Fuller and Phillips-Perron.

\subsubsection{Autoregressive Distributed Lag Bound testing}

ARDL bound testing approach is used in this study to check the impact of exchange rate on balance of trade on Pakistani data. ARDL is used to measure the short run and long run cointegration. There are some assumptions before using ARDL. Data must be free from serial correlation, normality issues. Data must not be stationary at second difference. There are some steps for ARDL bound testing approach.

1. The following equation was estimated for ARDL bound testing approach for measuring exchange rate and its impact on balance of trade.

$$
\begin{gathered}
\Delta B O T_{t}=\beta_{O}+\sum_{t-1}^{w} \beta_{1} i \Delta B O T_{t-1}+\sum_{t-1}^{w} \beta_{2} i \Delta E X R_{t-1}+\sum_{t-1}^{w} \beta_{3} i \Delta M S_{t-1}+\sum_{t-1}^{w} \beta_{4} i \Delta I N F_{t-1}+\beta_{5} i \Delta B O T_{t-1} \\
+\beta_{6} i \Delta E X R_{t-1}+\beta_{7} i \Delta M S_{t-1}+\beta_{8} i \Delta I N F_{t-1}+\varepsilon_{t}
\end{gathered}
$$

2. When co-integration is exist between data, then second step is to find the long run model by using following equation.

$$
\Delta B O T_{t}=\beta_{O}+\sum_{t-1}^{w} \beta_{1} i \Delta B O T_{t-1}+\sum_{t-1}^{w} \beta_{2} i \Delta E X R_{t-1}+\sum_{t-1}^{w} \beta_{3} i \Delta M S_{t-1}+\sum_{t-1}^{w} \beta_{4} i \Delta I N F_{t-1}
$$


3. In final step, it is need to check the error correction mechanism for short run.

$$
\Delta B O T_{t}=\beta_{O}+\sum_{t-1}^{w} \beta_{1} i \Delta B O T_{t-1}+\sum_{t-1}^{w} \beta_{2} i \Delta E X R_{t-1}+\sum_{t-1}^{w} \beta_{3} i \Delta M S_{t-1}+\sum_{t-1}^{w} \beta_{4} i \Delta I N F_{t-1}+\eta_{1} E C T_{t-1+} \varepsilon_{t}
$$

\section{RESULTS AND INTERPRETATION}

\section{Table 1 Unit Root test result}

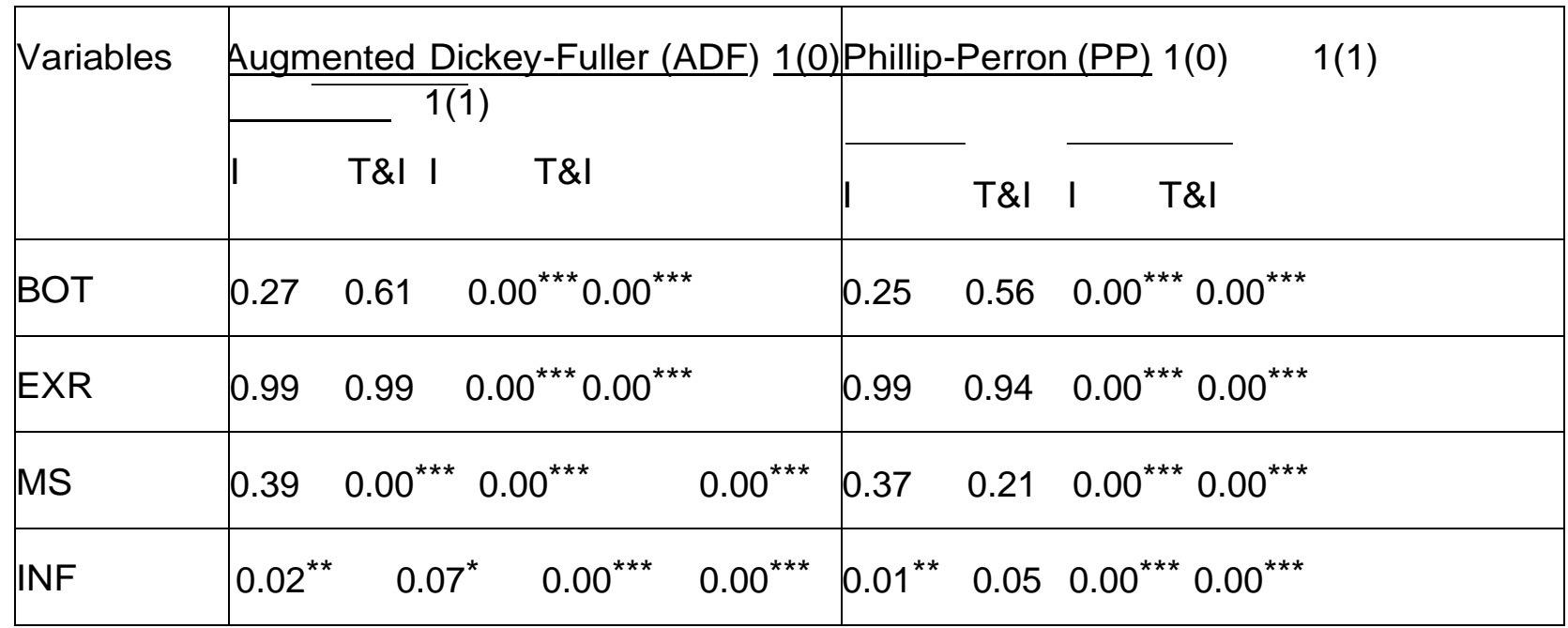

${ }^{* * *},{ }^{* *},{ }^{*}$ Show level of significant at $1 \%, 5 \%$ and $10 \%$ respectively

Table 1 shows the results of Augmented Dickey-Fuller (ADF) and Phillip-Perron (PP) which identify the stationarity of the data. Balance of trade, exchange rate, money supply and inflation are stationary at first difference for both ADF and PP. Only Inflation are stationary at level for both ADF and PP. No variable is stationary at 1(2), so we can proceed further for ADRL bound testing technique.

\subsection{Lag length Criterion}

Table 2. Lag length selection criteria for Co integration

\begin{tabular}{|l|l|l|l|l|l|l|}
\hline Lag & LogL & LR & FPE & AIC & SC & HQ \\
\hline 0 & -2144.637 & NA & $2.47 e+48$ & 122.7792 & 122.9570 & 122.8406 \\
\hline 1 & -1926.303 & 374.2864 & $2.37 e+43$ & 111.2173 & $112.1061^{*}$ & 111.5241 \\
\hline 2 & -1903.713 & 33.56266 & $1.69 e+43$ & 110.8407 & 112.4405 & 111.3930 \\
\hline
\end{tabular}




\begin{tabular}{|l|l|l|l|l|l|l|}
\hline 3 & -1877.615 & $32.80887^{*}$ & $1.05 e+43^{*}$ & $110.2637^{*}$ & 112.5745 & $111.0614^{\star}$ \\
\hline
\end{tabular}

Prior to apply co integration analysis, the lag order is determined through akaike information criterion (AIC) and Schwarz Bayesian criterion (SBC). Since the study use yearly time series data we used with a maximum of three lags. The calculated AIC and SBC figures with different lags were then evaluated which can be observed from the table 2 that at lag 3 the AIC criterion is significant however the SBC is significant at lag 1.we have selected in this study the AIC criterion for Lag selection.

\subsection{Determination of Co-integration by ARDL bound test}

Table 3 ARDL bound test result for co-integration $(1,3,3,4)$

Ho: There is no co-integration

\begin{tabular}{|l|l|l|}
\hline Test Statistic & Value & $\mathrm{k}$ \\
\hline F-statistic & 8.1670 & 3 \\
\hline & Critical Value Bounds & \\
\hline Significance & I(0) Lower & I(1)Upper \\
\hline $10 \%$ & 2.72 & 3.77 \\
\hline $5 \%$ & 3.23 & 4.35 \\
\hline $2.5 \%$ & 3.69 & 4.89 \\
\hline $1 \%$ & 4.29 & 5.61 \\
\hline
\end{tabular}

Table 2 shows the value of F-statistic is 8.1670 which is greater than lower and upper bounds at $1 \%$ level of significant. So it means that null hypothesis is rejected and conclude that there is co integration between variables of this study.

\subsection{Long Run Coefficient Results}

Table 4 Long Run Association ARDL (1, 3, 3, 4)

\begin{tabular}{|l|l|l|l|l|}
\hline \multicolumn{5}{|c|}{ Dependent Variable: BOT } \\
\hline Variables & Coefficient & Std. Error & t-Statistic & Prob. \\
\hline D(EXR) & 0.248138 & 0.058486 & 4.242717 & 0.0003 \\
\hline
\end{tabular}




\begin{tabular}{|l|l|l|l|l|}
\hline MS & -0.078579 & 0.021975 & -3.575775 & 0.0015 \\
\hline LNINF & -0.362621 & 0.115026 & -3.152503 & 0.0043 \\
\hline C & 4.399456 & 0.975392 & 4.510451 & 0.0001 \\
\hline
\end{tabular}

Table 3 shows the long-run association of independent variables with dependent variable. Exchange rate has positive and significant relationship with balance of trade in long run, Petrovic and Gligoric (2010) examined the relationship between trade balance and exchange rate in Serbia by using both Johansen and auto regressive distributive lag approaches. The result shows that real depreciation improves the trade balance in the long run.Money supply and inflation have significant but negative relationship with balance of trade. So all independent variables are cointegrated with dependent variable in long run.

\subsection{Diagnostic Tests}

\section{Table 4 Diagnostic Tests Results}

\begin{tabular}{|l|l|l|}
\hline Test Statistic & F version [p-value] & LM version [p-value] \\
\hline Serial Correlation & $0.742635[0.4874]$ & $2.592948[0.2735]$ \\
\hline Normality & N.A & $0.801613[0.2011]$ \\
\hline Heteroscedasticity & $0.351437[0.9828]$ & $3.207855[0.9551]$ \\
\hline
\end{tabular}

Table 4 shows the diagnostic tests of data. We used Serial correlation, Normality, and Heteroscedasticity. Results show that our data is free from serial correlation, normality issues, and heteroscedasticity problems by using optimum lag length criteria $(1,3,3,4)$.

\subsection{Error Correction Mechanism}

Table 5 Short Run Co-efficient Results ARDL (1, 3, 3, 4)

\begin{tabular}{|l|l|l|l|l|}
\hline Dependent Variable: BOT \\
\hline Variables & Coefficient & Std. Error & t-Statistic & Prob. \\
\hline $\mathrm{D}(\mathrm{BOT}(-1))$ & -0.218619 & 0.150923 & -1.448548 & 0.1604 \\
\hline $\mathrm{D}(\mathrm{BOT}(-1))$ & -0.218619 & 0.150923 & -1.448548 & 0.1604 \\
\hline $\mathrm{D}(\mathrm{BOT}(-2))$ & -0.362473 & 0.140234 & -2.584777 & 0.0163 \\
\hline $\mathrm{D}(\mathrm{EXR}, 2)$ & 0.016261 & 0.006131 & 2.652407 & 0.0139 \\
\hline
\end{tabular}




\begin{tabular}{|l|l|l|l|l|}
\hline$D(E X R(-1), 2)$ & -0.016315 & 0.006406 & -2.546969 & 0.0177 \\
\hline$D(E X R(-2), 2)$ & -0.024456 & 0.006794 & -3.599601 & $0.0014^{* *}$ \\
\hline$D(M S)$ & -0.006267 & 0.005981 & -1.047789 & 0.3052 \\
\hline$D(M S(-1))$ & 0.008007 & 0.010503 & 0.762338 & 0.4533 \\
\hline$D(M S(-2))$ & 0.020209 & 0.007904 & 2.556634 & $0.0173^{*}$ \\
\hline$D(L N I N F)$ & -0.027317 & 0.041118 & -0.664361 & 0.5128 \\
\hline$D($ LNINF(-1)) & 0.018589 & 0.050315 & 0.369451 & 0.715 \\
\hline$D(L N I N F(-2))$ & 0.02429 & 0.060323 & 0.402667 & 0.6908 \\
\hline$D($ LNINF(-3)) & 0.11502 & 0.047305 & 2.431453 & $0.0229^{* *}$ \\
\hline CointEq(-1) & -0.336195 & 0.086304 & -3.895476 & $0.0007^{*}$ \\
\hline ECM = BOT - (0.2481 D(EXR) -0.0786 MS -0.3626 LNINF + 4.3995) & \\
\hline R-squared & 0.913820 & Akaike info criterion (AIC) & -2.282978 \\
\hline Adjusted R-squared & 0.856367 & \multicolumn{5}{|l|}{ Schwarz criterion (SC) } & -1.572473 \\
\hline F-statistic & 15.90545 & Hannan-Quinn criterion. (HQ) & -2.024251 \\
\hline Prob. (F-statistic) & 0.000000 & Durbin-Watson stat & 2.240076 \\
\hline
\end{tabular}

${ }^{* *}$ Indicates significance at the $1 \%$ level.

${ }^{*}$ Indicates significance at the $5 \%$ level.

Table 4 shows the short run coefficients and error correction mechanism of the model. In shortrun exchange rate has significant and positive relationship with balance of trade in short run, Petrovic and Gligoric (2010) In the short run the trade balance first deteriorates before it later improves that is exhibiting the $\mathrm{J}$ curve pattern. The results obtained are helpful for the policy makers both in Serbia and in a number of other emerging countries as they face current account deficit.

Moreover, previous two-year value of money supply has positive and significant relationship with balance of trade in short run. Current year and previous year value of inflation has insignificant relationship with balance of trade while previous three-year value of inflation affect the balance of trade positively and significantly. The value of ECM is significant and negative which shows that model is moving towards equilibrium position. However, the speed of adjustment is $33 \%$. R-squared value is .91 which means that balance of trade is explained 
$91 \%$ by independent variables. DW stat shows that there is minor negative autocorrelation.

\subsection{Model Stability Tests (CUSUM \& CUSUM of Square)}

Figure 3 CUSUM

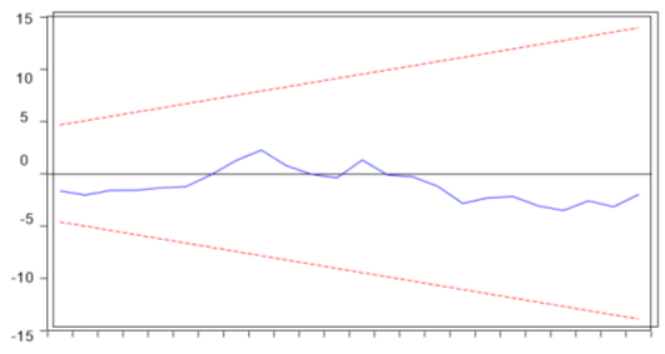

929496980002040608101214

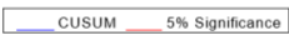

Figure 4 CUSUM of Square

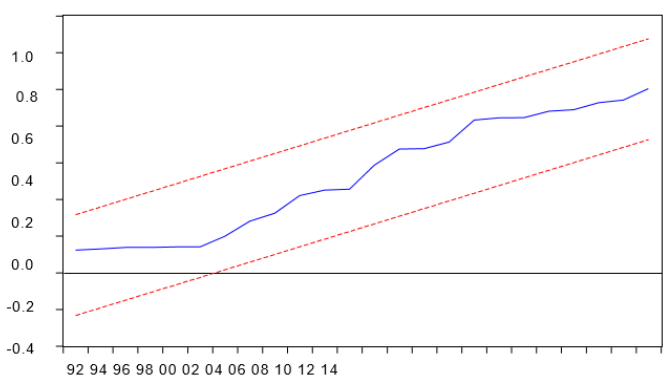

CUSUM of Squares $5 \%$ Significancel

We have checked the model stability through CUSUM and CUSUM of square. In both above figures, the blue lines are between red lines which means that our model is stable under $5 \%$ level of significant as you can see in Figure 3 and Figure 4. If the blue line go out from two critical lines, then it said to be instability of our model.

\section{Conclusion and recommendations}

The main goal of the study is to check the Effect of exchange rate Fluctuation on trade balance of trade in the presence of inflation and money supply in the context of Pakistan. We have used balance of trade as dependent variable while our independent variables are exchange rate, money supply, and inflation. The annual time series data from 1971 to 2016 was taken from world development indicator. The results reveal that exchange rate has positive and significant relationship with balance of trade in long run and short run. It means that Pakistani rupee is depreciated against USD. The devaluation of the currency will improve the exports and ultimately will boost the balance of trade in Pakistan. The inflation has negative and significant relationship with balance of trade in long run, but in short run, the three-year previous value of inflation has positive and significant impact on balance of trade. So, it means 
that in long run the inflation decreases the exports of the country and will promote the imports which ultimately tend to decrease balance of trade. The money supply has also negative and significant association with balance of trade in Pakistan in long run, but in short run, the previous two-year value of money supply has positive and significant relationship with balance of trade. Due to inflation in the country, the money supply is increased which also diminish the trade balance in Pakistan. This study has a policy implications for government as well as local and foreign investors. The government should also play an important role to make such strategies which can increase the balance of trade in Pakistan and could cause indirectly boost the economic growth of Pakistan.

\section{REFERENCES}

Bahmani-Oskooee, M., 1998. Do exchange rates follow a random walk process in Middle Eastern countries?. Economics Letters, 58(3), pp.339-344. https://doi.org/10.1016/S0165-1765(98)00013-5

Bahmani-Oskooee, M., 1991. Is there a long-run relation between the trade balance and the real effective exchange rate of LDCs?. Economics letters, 36(4), pp.403-407. https://doi.org/10.1016/0165-1765(91)90206-Z

Bahmani-Oskooee, M. and Malixi, M., 1992. More evidence on the J curve from LDCs. Journal of Policy Modeling, 14(5), pp.641-653. https://doi.org/10.1016/0161-8938(92)90034-A

Briguglio, L., 1989. The impact of a devaluation on the Maltese trade balance with special reference to the price and income reversal effects. Applied economics, 21(3), pp.325-337. https://doi.org/10.1080/758522550

Buluswar, M.D., Thompson, H. and Upadhyaya, K.P., 1996. Devaluation and the trade balance in India: stationarity and cointegration. Applied Economics, 28(4), pp.429-432. https://doi.org/10.1080/000368496328551

Brada, J.C., Kutan, A.M. and Zhou, S., 1997. The exchange rate and the balance of trade: the Turkish experience. The Journal of Development Studies, 33(5), pp.675-692. https://doi.org/10.1080/00220389708422489

Bahmani-Oskooee, M. and Cheema, J., 2009. Short-run and long-run effects of currency depreciation on the bilateral trade balance between Pakistan and her major trading partners. Journal of Economic Development, 34(1), p.19.

Gafar, J., 1981. Devaluation and the balance of payments adjustment in a developing economy: an analysis relating to Jamaica: 1954-72. Applied Economics, 13(2), pp.151-165. https://doi.org/10.1080/00036848100000021

Himarios, D., 1989. Do devaluations improve the trade balance? The evidence revisited. Economic inquiry, 27(1), pp.143168. https://doi.org/10.1111/j.1465-7295.1989.tb01169.x

Kemal, M.A. and Qadir, U., 2005. Real exchange rate, exports, and imports movements: A trivariate analysis. The Pakistan Development Review, pp.177-195. https://doi.org/10.30541/v44i2pp.177-195

Shah, A. and Majeed, M.T., 2014. Real exchange rate and trade balance in Pakistan: An ARDL co-integration approach.

Saqib, N., 2014. The Effect of Exchange Rate Fluctuation on Trade Balance: Empirical Evidence from Saudi Arab Economy Classification-JEL. Journal of Knowledge Management, Economics and Information Technology, 4(1), pp.1-1. https://doi.org/10.2139/ssrn.3288744

Zakaria, M., Ahmad, E. and lqbal, M.M., 2007. NOMINAL EXCHANGE RATE VARIABILITY: A CASE STUDY OF PAKISTAN. Journal of Economic Cooperation Among Islamic Countries, 28(1).

Dodzin, S. and Vamvakidis, A., 2004. Trade and industrialization in developing economies. Journal of Development Economics, 75(1), pp.319-328. https://doi.org/10.1016/j.jdeveco.2003.08.006 
Schneider, F., 2002, July. Size and measurement of the informal economy in 110 countries. In Workshop of Australian National Tax Centre, ANU, Canberra.

Mohammad, S., 1981. Trade, growth and income redistribution: A case study of India. Journal of Development Economics, 9(1), pp.131-147. https://doi.org/10.1016/0304-3878(81)90008-0

Heal, G. and McLeod, D., 1984. Gains from trade, stability and profits: A comment on Chichilnisky's 'Terms of trade and domestic distribution: export-led growth with abundant labour'. Journal of Development Economics, 15(1-3), pp.117-130. https://doi.org/10.1016/0304-3878(84)90010-5

Qureshi, M.S., 2013. Trade and thy neighbor's war. Journal of Development Economics, 105, pp.178-195. https://doi.org/10.1016/j.jdeveco.2013.07.009

Yu, Q., 1998. Capital investment, international trade and economic growth in China: Evidence in the 1980-90s. China Economic Review, 9(1), pp.73-84. https://doi.org/10.1016/S1043-951X(99)80005-4

Echevarria, C., 2008. International trade and the sectoral composition of production. Review of Economic Dynamics, 11(1), pp.192-206. https://doi.org/10.1016/j.red.2007.06.004 